\title{
Breast-feeding protects against respiratory syncytial virus infections
}

\author{
M A P S DOWNHAM, R SCOTT, D G SIMS, J K G WEBB, P S GARDNER
}

British Medical fournal, 1976, 2, 274-276

\section{Summary}

Eight out of 115 infants admitted to hospital with respiratory syncytial (RS) virus infection had been breastfed compared with 46 out of 167 controls; this difference was statistically significant. Twenty-one specimens of human colostrum were examined, and all contained RS virus neutralising activity. Specific $\operatorname{IgA}$ and $\operatorname{IgG}$ were detected in 18 specimens, whereas IgM was detected in none. The titre of IgA antibody was usually higher and correlated more closely to the titre of neutralising activity than that of IgG. Infants inhale milk feeds and regurgitate them through the nose, and the IgA collecting in the respiratory tract might protect against severe respiratory infection. Alternatively, if severe RS virus illness is a sign of hypersensitivity to the virus breastfeeding might protect the infant from an early sensitising infection.

\section{Introduction}

For many years morbidity and mortality rates for breast-fed infants have been noted to be lower than for those fed on cows' milk. ${ }^{1-3}$ Resistance factors, specific and non-specific, against a wide range of bacteria and some enteroviruses have been shown in human milk. ${ }^{4}$ Evidence that these resistance factors are responsible for the epidemiological advantages to breast-fed infants is incomplete and is especially difficult to gather in countries where high standards of hygiene have resulted in relatively low rates of clinically significant gastrointestinal infection and where breast feeding is relatively uncommon.

Little is known about the relation between breast-feeding and respiratory virus infections. In developed countries these are now the commonest type of infection requiring admission to hospital during infancy and a major factor in postneonatal deaths. ${ }^{5}$ It is important, therefore, to know whether breast-feeding gives any protection against them.

We report here epidemiological evidence that breast-feeding protects against infection with respiratory syncytial (RS) virus, the most important respiratory pathogen in infancy, and the results of some preliminary investigations into the mechanism of this protection.

\section{Methods \\ EPIDEMIOLOGICAL STUDY}

As part of a wider study the mothers of 115 infants admitted to hospital during the winter of 1973-4 with RS virus infection were asked about the length of time that the baby had been breast-fed. The

Departments of Child Health and Virology, University of Newcastle upon Tyne

M A P S DOWNHAM, MRCP, DCH, first assistant in child health

R SCOTT, BSC, PHD, senior research officer in virology

D G SIMS, MRCP, senior research associate in child health and virology

J K G WEBB, MA, FRCP, professor of child health

P S GARDNER, MD, DIPBACT, professor of clinical virology same question was put to mothers of 167 infants interviewed without $\frac{O}{0}$ selection in the waiting rooms of Newcastle city child health clinics $\frac{c}{\partial}$ during the same RS virus epidemic. Follow-up of these control infants $\overline{\bar{s}}$ established that they had not been admitted to hospital with respiratory $\vec{\nabla}$ illness during that winter. All children were aged less than 12 months; the mean age of the children admitted with RS virus infection was $4 \cdot 1$ months and of the control children $4 \cdot 7$ months.

\section{LABORATORY STUDIES}

As a separate investigation a sample of colostrum was taken from 21 mothers 10 minutes to 48 hours after delivery. The colostra were ? centrifuged at $600 \mathrm{~g}$ for 90 minutes and the supernatants stored at 8 $-20^{\circ} \mathrm{C}$. Neutralising activity against RS virus in each specimen of $\mathcal{O}^{\circ}$ colostrum was determined by the plaque reduction technique ${ }^{6}$

The nature and specificity of the neutralising activity were inves- $\neg$ tigated by a membrane fluorescent antibody technique. ${ }^{7}$ Unfixed RS 을 virus infected tissue culture cells were treated with dilutions of colostrum and then stained with antihuman $\operatorname{IgA}, \mathrm{IgG}$, and $\mathrm{IgM}$. The anti-immunoglobulin sera were raised in sheep (Wellcome Reagents Limited). The specificity of fluorescence obtained with RS virusinfected cells was controlled for each specimen of colostrum examined $\vec{\varphi}$ by staining negative cells in parallel.

\section{Results}

\section{EPIDEMIOLOGICAL STUDIES}

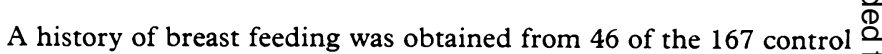
children but from only eight of the 115 children admitted to hospital $\overrightarrow{\vec{O}}$ with RS virus infection $\left(\gamma^{2}=18.65 ; P<0.0005\right)$. None of these eight 3 children were still being breast-fed at the time of the RS virus illness, whereas eight of the control children were still being breast-fed at the time of the interview.

The duration of breast-feeding in both groups of children is shown in table I. In 29 of the 54 breast-fed children breast-feeding had been discontinued by the age of 1 month, but even this duration of 0 breast-feeding seemed to confer a significant advantage over those who were never breast fed $\left(\varkappa^{2}=9.22 ; \mathrm{P}<0.005\right)$.

TABLE I-Age at which breast-feeding was discontinued

\begin{tabular}{|c|c|c|c|c|c|}
\hline Age (months): & $<1$ & $1-2$ & -3 & -4 & $>4$ \\
\hline $\begin{array}{l}\text { Children admitted with RS virus } \\
\text { Controls }\end{array}$ & $\begin{array}{r}5 \\
24\end{array}$ & 9 & 7 & $\begin{array}{l}1 \\
4\end{array}$ & $\frac{1}{2}$ \\
\hline
\end{tabular}

We attempted to examine the possibility that factors other than breast feeding, related to social class differences between the control + and index groups, might have been responsible for the lower incidence $\frac{T}{T}$ of admission to hospital with RS virus infection in the control group. Table II compares the social class distribution of the index and control $\stackrel{D}{\circ}$ children with that of all births registered in Newcastle upon Tyne in $\mathbb{\Phi}$ 1969. ${ }^{8}$ There were significantly more children in social classes IV and $\frac{0}{O}$ $\mathrm{V}$ and "others" among those admitted with RS virus than among the controls $\left(\%^{2}=9.53 ; P<0.005\right)$, whereas the social class distribution of $O$ the control group was very similar to that shown in the 1969 Newcastle maternity survey.

We therefore compared the apparent effect of breast feeding within different social class groupings (table III). Within social classes I, II, III (non-manual), and III (manual), there were significantly more breast-fed babies among control babies than among those admitted to hospital with RS virus infection. This difference, however, was not significant within social classes IV and V and others. 
TABLE II-Social class breakdown of study groups with Newcastle maternity survey for comparison

\begin{tabular}{|c|c|c|c|}
\hline & $\begin{array}{l}\text { Children } \\
\text { admitted with } \\
\text { RS virus }\end{array}$ & Controls & $\begin{array}{c}1969 \text { Newcastle } \\
\text { Maternity Survey } \\
(\mathrm{n}=3289)\end{array}$ \\
\hline $\begin{array}{l}\text { I } \\
\text { II } \\
\text { III N } \\
\text { III } \mathrm{M} \\
\text { IV } \\
\text { V } \\
\text { Others* }\end{array}$ & $\left.\begin{array}{l}\left.\begin{array}{r}2 \\
6 \\
5\end{array}\right\} 11^{\circ} \circ \\
46 \\
17 \\
21 \\
18\end{array}\right\} 49^{\circ} \circ$ & $\begin{array}{r}\left.\begin{array}{r}7 \\
17 \\
10 \\
82 \\
11 \\
25 \\
15\end{array}\right\} 20 \% 0 \\
01 \%\end{array}$ & $\left.\begin{array}{r}152 \\
248 \\
298 \\
1445\end{array}\right\} 21 \%$ \\
\hline
\end{tabular}

*Most were unemployed. III N = III (non-manual). III $M=$ III (manual).

TABLE III-Early feeding practice in both groups according to social class

\begin{tabular}{|c|c|c|c|}
\hline & $\begin{array}{l}\text { Children } \\
\text { admitted with } \\
\text { RS virus }\end{array}$ & Controls & Significance \\
\hline \multicolumn{4}{|c|}{ Classes $I, I I$, and III $N$} \\
\hline $\begin{array}{l}\text { Breast-fed } \\
\text { Not breast-fed }\end{array}$ & $\begin{array}{r}2 \\
11\end{array}$ & $\begin{array}{l}21 \\
13\end{array}$ & $\chi^{2}=8.09, P<0.005$ \\
\hline \multicolumn{4}{|c|}{ Class III M } \\
\hline $\begin{array}{l}\text { Breast-fed } \\
\text { Not breast-fed }\end{array}$ & $\begin{array}{r}2 \\
44\end{array}$ & $\begin{array}{l}16 \\
66\end{array}$ & $x^{2}=5.61, P<0.025$ \\
\hline \multicolumn{4}{|c|}{ Classes $I V$ and $V$ and others } \\
\hline $\begin{array}{l}\text { Breast-fed } \\
\text { Not breast-fed }\end{array}$ & $\begin{array}{r}4 \\
52\end{array}$ & $\begin{array}{r}9 \\
42\end{array}$ & $l^{2}=2.76, P<0.1$ \\
\hline
\end{tabular}

\section{LABORATORY INVESTIGATIONS ON COLOSTRUM}

The titre of neutralising activity to $\mathrm{RS}$ virus was taken as the highest dilution of colostrum that gave a $60 \%$ or greater reduction in plaque count. The intensity of membrane fluorescence in the indirect fluorescent antibody technique was graded from + to ++++ . The titre of antibody to RS virus detected by the technique was taken as the highest dilution of colostrum to give $a+$ to ++ reading.

The titres of RS virus neutralising activity and RS virus membrane fluorescent antibody are shown for each specimen of colostrum in table IV. Neutralising activity was detected in all specimens examined and ranged from $1 / 4$ to $1 / 4096$. Specific IgA antibody to RS virus was found in 18 out of 21 specimens of colostrum. The remaining three specimens showed a non-specific fluorescence on staining with antiIgA conjugate. Specific IgG antibody to RS virus was detected in 18 specimens at a titre of $1 / 10$ or greater and at a titre of less than $1 / 10$ in the other three specimens examined. Specific IgM antibody to RS virus was not detected in any of the specimens of colostrum examined by membrane fluorescence. The titre of IgA antibody was usually higher and showed a closer correlation to the titre of neutralising activity than that of IgG.

\section{Discussion}

The incidence of breast-feeding among infants admitted to hospital with $\mathrm{RS}$ virus infection was significantly lower than that among the control children. This suggests that human milk may have an advantage over cows' milk in protecting from RS virus infection. Many of the control infants probably had mild RS virus infections during the epidemic. For example, one study showed that about $90^{\circ}{ }_{0}$ of 2 -year-old children had serological evidence of past infection with RS virus. ${ }^{9}$ Breast-feeding, therefore, seems to offer protection against illness severe enough to require hospital admission even though the occasional occurrence of frank bronchiolitis in fully breast-fed infants makes it clear 1 that this protection is not complete. Glezen and Denny speculated that breast-feeding might delay the age of onset and clinical severity of RS virus infection. ${ }^{10}$

Our conclusion that breast-feeding is protective rests on the validity of the control group. This was well matched for age but not for social class distribution (see table III). When comparisons were made within the social class groups, however, breastfeeding seemed to have an effect independent of social class at least for social classes I, II, III (non-manual), and III (manual). This was not shown significantly for social classes IV and V and
TABLE IV-Neutralising activity and specific antibody to $R S$ virus in colostra

\begin{tabular}{|c|c|c|c|}
\hline \multirow{2}{*}{$\begin{array}{l}\text { Colostrum } \\
\text { specimen No }\end{array}$} & \multirow{2}{*}{\begin{tabular}{|} 
Titre of neutralising \\
activity to RS \\
virus in \\
colostrum
\end{tabular}} & \multicolumn{2}{|c|}{$\begin{array}{l}\text { Titre of membrane fluorescent antibody } \\
\text { to RS virus in colostrum }\end{array}$} \\
\hline & & $\operatorname{IgA}$ & IgG \\
\hline $\begin{array}{r}1 \\
2 \\
3 \\
4 \\
5 \\
6 \\
7 \\
8 \\
9 \\
10 \\
11 \\
12 \\
13 \\
14 \\
15 \\
16 \\
17 \\
18 \\
19 \\
20 \\
21\end{array}$ & $\begin{array}{l}1 / 4 \\
1 / 8 \\
1 / 16 \\
1 / 16 \\
1 / 32 \\
1 / 32 \\
1 / 32 \\
1 / 32 \\
1 / 64 \\
1 / 128 \\
1 / 128 \\
1 / 256 \\
1 / 256 \\
1 / 256 \\
1 / 256 \\
1 / 256 \\
1 / 256 \\
1 / 512 \\
1 / 1024 \\
1 / 1024 \\
1 / 4096\end{array}$ & $\begin{array}{c}\text { Non-specific } \\
1 / 40 \\
1 / 10 \\
\text { Non-specific } \\
1 / 10 \\
1 / 30 \\
1 / 20 \\
1 / 20 \\
1 / 10 \\
1 / 10 \\
1 / 20 \\
1 / 40 \\
1 / 160 \\
1 / 40 \\
\text { Non-specific } \\
1 / 40 \\
1 / 60 \\
1 / 80 \\
1 / 100 \\
1 / 200 \\
1 / 200\end{array}$ & $\begin{array}{r}1 / 10 \\
1 / 10 \\
1 / 10 \\
1 / 20 \\
1 / 10 \\
<1 / 10 \\
<1 / 10 \\
1 / 80 \\
1 / 20 \\
1 / 10 \\
1 / 10 \\
<1 / 10 \\
1 / 40 \\
1 / 10 \\
1 / 10 \\
1 / 10 \\
1 / 10 \\
1 / 20 \\
1 / 40 \\
1 / 20 \\
1 / 40\end{array}$ \\
\hline
\end{tabular}

others (principally unemployed), but only few children in this group had been breast-fed.

Evidence that the incidence of breast-feeding in our controls $(27.5 \%)$ was not exceptional for Newcastle is provided by figures available for breast-feeding from the two main maternity hospitals during the last six months of 1973 . At one $31.7 \%$ of the mothers attempted to breast-feed, and $28.6 \%$ were breastfeeding when discharged from hospital; at the other the figure for attempted breast-feeding is not available, but $18.2 \%$ of the mothers were breast-feeding at the time of discharge.

A further consideration is the doubtful value of social class based on the father's occupation as an assessment of family circumstances. Neligan et al have shown in relation to the growth and development of Newcastle children that when weighting is given to the "mother's care of child" and other features as assessed by a health visitor over three years the previously significant contribution of social class based on father's occupation is eliminated. ${ }^{11}$ We do not have similar information about the care of the children in our study. By recruiting our controls at child health clinics, we may have selected a group of mothers whose standard of care was unrepresentatively high, so that breast-feeding may have been only one of several advantages combining to protect their children against RS virus infection requiring admission to hospital. We know, however, that $82 \%$ of Newcastle city infants were seen at child health clinics in $1972.1^{22}$ Most of our control children were recruited from clinics in the poorer areas of the city, and it seems unlikely that standards of care differed widely between our two groups.

Human milk has haemagglutination-inhibiting action against influenza A with titres of up to $1 / 512$ in colostrum, the levels falling over the few weeks after delivery to constant low levels which persist for up to five months. Cows' milk has no natural concentration of haemagglutination-inhibiting antibody against influenza A. ${ }^{13}$ Our laboratory studies show that colostrum invariably contains neutralising activity against RS virus and that at least part of this activity is almost certainly contained in IgA. A close correlation between neutralising activity and specific IgA antibody may be masked by the presence of varying amounts of other virus inhibitors present in colostrum. We can only speculate about the possible mechanisms by which ingested IgA might protect against respiratory infection. Radiological studies have shown that infants inhale milk during feeding, ${ }^{14}{ }^{15}$ and they are known to regurgitate feed through the nose. Breast-feeding even for less than one month after birth appears to be protective, suggesting that if inhaled IgA plays a part, it must persist in the respiratory tract for some time. Alternatively severe RS virus illness may be a manifestation of hypersensitivity to the virus, ${ }^{16}$ in which case the main benefit of breast-feeding might lie in protection against an early sensitising infection.

Although further work is needed to establish the mechanisms, 
we believe that our results present strong evidence that breastfeeding provides protection against $\mathrm{RS}$ virus infection. This virus has been identified as a major factor in postneonatal morbidity and mortality. These observations can be added to the growing list of benefits for breast-feeding. There is general and official agreement that breast feeding should be encouraged more widely, ${ }^{17}$ but evidence of the kind we have presented, which suggests an advantage readily understood by the general public, should help to strengthen the case for this policy.

We thank Professor F E Hytten for help with the arrangements for collecting samples of colostrum and $\mathrm{Mr}$ Paul Clark for statistical help. We acknowledge the continuing support of the Medical Research Council.

\section{References}

${ }^{1}$ Newman, G, Infant Mortality. London, Methuen, 1906.
${ }^{2}$ Grulee, C G, Sanford, H N, and Herron, P H, Fournal of the American Medical Association, 1934, 103, 735.

${ }^{3}$ Robinson, M, Lancet, 1951, 1, 788.

4 Goldman, A S, and Smith, C W, Fournal of Paediatrics, 1973, 82, 1082.

${ }^{5}$ Downham, M A P S, et al, British Medical fournal, 1975, 1, 235.

6 Scott, R, and Gardner, P S, Fournal of Hygiene, 1970, 68, 581.

7 Scott, R, et al, Clinical and Experimental Immunology, in press.

${ }^{8}$ Barron, S L, Newcastle Maternity Survey, personal communication.

9 Hambling, M H, Fournal of Pathology and Bacteriology, 1966, 91, 625.

10 Glezen, W P, and Denny, F W, New England fournal of Medicine, 1973, 288, 498 .

11 Neligan, G A, et al, in preparation.

12 Medical Officer of Health's Report for Newcastle upon Tyne, p 41. 1972.

${ }^{13}$ Schmidt, E, Zeitschrift fur Kinderheilkunde, 1960, 84, 339.

${ }^{14}$ De Carlo, J, Tramer, A, and Startzman, H, American fournal of Diseases of Childhood, 1952, 84, 442.

${ }^{15}$ Frank, M M, and Gatewood, O M, American fournal of Diseases of Childhood, 1966, 111, 178.

16 Gardner, P S, McQuillin, J, and Court, S D M, British Medical fournal, $1970,1,327$

17 Department of Health and Social Services, Present Day Practice in Infant Feeding, p 24. London, HMSO, 1974.

\title{
Lymphocyte cytotoxicity for kidney cells in renal tubular acidosis of autoimmune liver disease
}

\author{
A M G COCHRANE, D C TSANTOULOS, A MOUSSOUROS, I G McFARLANE, \\ A L W F EDDLESTON, ROGER WILLIAMS
}

British Medical fournal, 1976, 2, 276-278

\begin{abstract}
Summary
Sensitisation to a renal tubular antigen, Tamm-Horsfall glycoprotein, has been shown to be common in patients with renal tubular acidosis complicating autoimmune liver disease, and it has been suggested that this immune reaction, by damaging renal tubular cells, might be responsible for the acidification defect. The lymphocytes from 10 out of 13 patients with chronic active hepatitis or primary biliary cirrhosis and an associated renal tubular acidosis were shown to be cytotoxic for a kidney cell line known to secrete Tamm-Horsfall glycoprotein. The cytotoxic reaction was blocked by this antigen, but not by two other proteins, indicating that sensitisation to the renal glycoprotein was the likely cause of the target cell damage. Significant reduction in cytotoxicity after the addition of aggregated IgG suggested that the reaction was of the antibody-dependent cell-mediated type. These results, together with the finding of antigenic material in the surface membrane of liver cells that cross reacts immunologically with Tamm-Horsfall glycoprotein, provide an explanation for the association between chronic liver disease and renal tubular dysfunction.
\end{abstract}

Liver unit, King's College Hospital and Medical School, London SE5 9RS

A M G COCHRANE, MB, MRCP, senior registrar

D C TSANTOULOS, MD, research fellow

A MOUSSOUROS, MD, research fellow

I G MCFARLANE, BSC, PHD, senior research biochemist

A L W F EDDLESTON, DM, MRCP, lecturer and honorary consultant physician

ROGER WILLIAMS, MD, FRCP, consultant physician and director of unit

\section{Introduction}

On systematic investigation of patients with primary biliary cirrhosis or chronic active hepatitis there is often evidence of disease in other organs and this, like the liver damage, has been attributed to an autoimmune reaction. ${ }^{1}$ One of the commonest associations is with renal tubular acidosis, which in one study was found in an incomplete form in $32 \%$ of 228 cases. ${ }^{1}$ Using the leucocyte migration test and a kidney homogenate as antigen, Smith et $a l^{2}$ found sensitisation in $59 \%$ of patients with renal tubular acidosis. More recently we have shown sensitisation to a specific antigen present in this homogenate, the Tamm-Horsfall glycoprotein, in $91 \%$ of such patients. ${ }^{3}$ This antigen is secreted in the distal part of the nephron at the principal site of urinary acidification, ${ }^{4}$ and we suggested that the acidification defect in renal tubular acidosis might be due to immunologically mediated damage to the renal tubular cells in this region. To test this hypothesis we have investigated the cytotoxicity of lymphocytes from such patients for a cell line, derived from baby hamster kidney, which is known to produce a glycoprotein immunologically similar to the Tamm-Horsfall glycoprotein. ${ }^{5}$ We also studied the relation of this cytotoxic reaction to that directed against hepatocytes in patients with chronic active hepatitis. ${ }^{6}$

\section{Patients and methods}

Twenty patients with chronic active hepatitis and five with primary biliary cirrhosis were investigated, the diagnosis having been confirmed histologically in all cases. Apart from two of the newly diagnosed patients all the others with chronic active hepatitis were receiving either prednisone $15 \mathrm{mg}$ or prednisone $10 \mathrm{mg}$ plus azathioprine $75 \mathrm{mg}$ at the time of investigation. The five patients with primary biliary cirrhosis were taking part in an international double-blind trial of azathioprine versus placebo. None of the patients had metabolic acidosis, but in 10 of those with chronic active hepatitis and three with primary biliary cirrhosis the incomplete type of renal tubular acidosis was shown to be present, using an acid load test. After a single oral load of $37.5 \mathrm{mmol}(75 \mathrm{mEq})$ of calcium chloride urine was collected 